\title{
TE INTEGRATION OF WATER HYDRODYNAMICS MODELLING AND REMOTE SENSING DATA TO IMPROVE THE WATER CIRCULATION OF LAKE MANZALA, EGYPT
}

\author{
$\underline{\text { M A Bek }}^{1}$, Sameh B. Elkafrawy ${ }^{2}$, I S Lowndes ${ }^{3}$, D M Hargreaves $^{3}$ \\ ${ }^{1}$ Department of Physics and Engineering Mathematics, Faculty of Engineering, Tanta University, Egypt \\ M.ali@f-eng.tanta.edu.eg
}

${ }^{2}$ Marine Science Department, National Authority for Remote Sensing and Space Sciences, (NARSS) Egypt

${ }^{3}$ Process and Environmental Research Division, Faculty of Engineering, University of Nottingham, UK

\begin{abstract}
:
This paper presents the preliminary results of the application of the ocean model (FVCOM) to replicate the hydrodynamic flows experienced within Lake El-Manzala, Egypt. The construction of this model is used to characterize the ecosystem of this shallow brackish lake and assess a range of sustainable water management strategies. Lake El-Manzala is the largest of the Egyptian shallow coastal lakes on the fringe of the Mediterranean Sea. The lake currently supports $30 \%$ of the fresh water fish farm production of Egypt. In recent years the aquatic health of the lake has significantly deteriorated due to an increase in the contamination of the lake by polluted inflows and over intensive aquaculture. The focus of this study is to develop a model that may be employed to investigate the causes, effects and potential solutions to the pollutant loads imposed on the lake. The model has been used to study the hydrodynamic effect that a $40 \%$ reduction in the polluted drain water inflows to the lake due to a diversion of this water towards the Sinai for land development. This study concluded that in the western zone of the lake this action slightly changed the magnitude and direction of the water flows and an increase in the salinity levels. Several other lake management scenarios were proposed and the environmental effects on the lake water quality are under investigation. It is concluded that the hydrodynamic models developed may be used to study the cause and effects of other aquatic pollution problems and permit the investigation of potential engineering solutions to improve water quality management.
\end{abstract}

Keywords: Hydrodynamic modelling; shallow water lakes; Lake El-Manzala; FVCOM.

\section{Introduction}

Lake El-Manzala (Figure 1) is the biggest of the northern Egyptian lakes. The surface area of the lake is $700 \mathrm{~km}^{2}$, and has an average depth of 1 metre. Large drainage discharges from urban and industrial wastewater and agricultural runoff are the main source of water inflow to the lake. Six major drains contribute a flowrate of 4170 million cubic meters annually. The Bahr El Bauer drainage channel, located at the south east corner of the lake carries the untreated urban domestic and industrial waste water from Cairo $170 \mathrm{~km}$ away. This water is highly polluted with heavy metals, nutrients and toxic organics (Shakweer [2005], Khedr [2005], Wahaab et al. [1997], Siegel et al [1994], Khalil [1990], Abdel-Moati and Dowidar [1988]). There are two discharge channels connected to the Mediterranean Sea. The major discharge channel to the sea is located on the north east edge of the lake. The second discharge channel is connected to a large salt water buffer lagoon. The low Mediterranean Sea tides are observed to produce little hydrodynamic affect on the lake, other than to increase the relative salinity of the lake in the vicinity of the coastal discharge channels. 
Coastal lakes and lagoons present an important water resource across many parts of the world. They serve as reservoirs and contribute to the fishery and aquaculture industries. In economic terms, Lake El-Manzala provides one of the most important Egyptian farmed fish resources. A recent research study has confirmed that the lake supports a highly productive fishing industry with an annual catch of approximately 8,000 tonnes of different fish species Kraiernet al. [2009], which accounts for almost $50 \%$ of the annual coastal lakes fish productivity Donia and Ahmed [2006].The physical, chemical and biological quality of the water within Lake El-Manzala have been observed to dramatically deteriorate over the last few decades. This has been documented by numerous observational field studies (Abdel-Star and Geneid [2009], Shakweer [2005], Khedr [2005], Wahaab [1997], Khalil [1990]). The maintenance of the aquatic health of Lake El-Manzala is a high priority for the Egyptian government, UNDP [1997]. A quick resolution of the current environmental and water management problems is essential to allow the lake to survive ecologically. Consequently, there is a need to develop field validated hydrodynamic and ecological models that may be used to investigate suitable water quality and management strategies.

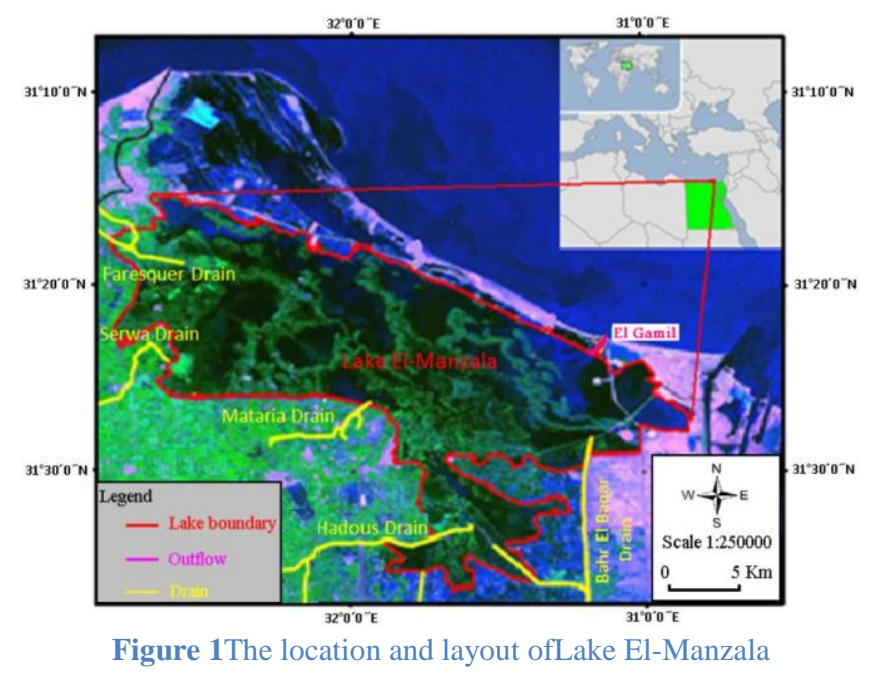

A recent modelling study by Rasmussen et al. [2009] investigated the influence that a reduced inflow nutrient load may have on the lake water quality. However, the model developed for this study did not consider the effect that a $40 \%$ reduction in the main water inflows may have on the lake ecosystem due to a diversion of this water towards the Sinai for land development. It is proposed that this reduction may adversely affect the water quality and change the water salinity distribution within the fringes of the lake nearest the sea. This work is considered as a first step toward constructing an operational finite volume hydrodynamic-ecological model for LakeEl-Manzala.

\section{Method}

Lake El-Manzala is located at the northern eastern edge of the Nile Delta. The Lake is almost rectangular in shape its long axis running from the North West to South East. The average depth of the lake is approximately $1 \mathrm{~m}$. A characteristic feature of Lake El-Manzala is the presence of a large number of islets, of sand or clay, created by a combination of natural sedimentation and dredging operations to facilitate the construction of fish pens. These islets divide the Lake into about 30 interconnected basins (Fig. 1) Most of these islets are inhabited by fishermen and farmers. Due to land reclamation, the surface area of the lake has been decreasing steadily over the past few decades from $1709 \mathrm{~km}^{2}$ in 1907 to $1470 \mathrm{~km}^{2}$ in 1949 and to $1260 \mathrm{~km}^{2}$ during 1960 's reaching to $895 \mathrm{~km}^{2}$ in 1979. Now, the surface area of Lake El-Manzala has been reduced to only $120 \mathrm{~km}^{2}$. The main 
physical characteristics of the lake are summarized in (Table 1). The ecosystem of the lake is underintensive pressure from human activities that are rapidly changing its water quality and environmental health. The major challenges being faced are the increase in illegal land reclamation and construction of new fish enclosures. These practices reduce the available lake volume and restrict the free hydrodynamic flows within the lake. The lake basin is in effect made up of several interconnected or isolated lake ponds which support different water qualities and sedimentation characteristics. Many of the drainage inflows to the lake are heavily polluted. In particular, the Bahr El Baqar drain which transports urban sewage and industrial waste from Cairo is responsible for the major pollutant loads delivered to the lake.

Table 1Lake El-Manzala Physical and Demographic Data (Thompson et al. [2009], Rasmussen et al. [2009], Shakweer [2005], Khalil [1990]).

\begin{tabular}{|l|l|}
\hline Location & $\begin{array}{l}31^{\circ} 45^{\prime}-32^{\circ} 15 \mathrm{E} 31^{\circ} 00^{\prime}- \\
31^{\circ} 30 \mathrm{~N}\end{array}$ \\
\hline Area & $600 \mathrm{~km}^{2}$ \\
\hline Catchment area including lake & $155 \mathrm{~km}^{2}$ \\
\hline Average depth - Maximum & $1 \mathrm{~m}-3.5 \mathrm{~m}$ \\
\hline $\begin{array}{l}\text { Average sediment accumulation } \\
\text { rate }\end{array}$ & $1.9-2.2 \mathrm{~kg} \mathrm{~m}^{-2} \mathrm{yr}^{-1}$ \\
\hline Annual precipitation & $1020 \mathrm{mmyr}^{-1}$ \\
\hline Annual evaporation & $78.4 \mathrm{mmyr}^{-1}$ \\
\hline Suspended particulate matter & $129-261 \mathrm{mg} \mathrm{m}^{-3}$ \\
\hline pH & 7.8 \\
\hline Salinity & $3000 \mathrm{mg} / \mathrm{L}-3500 \mathrm{mg} / \mathrm{L}$ \\
\hline Water Temperature & $30.5^{\circ} \mathrm{C} \mathrm{max.} 11.3^{\circ} \mathrm{C} \mathrm{min}$. \\
\hline Conductivity & $3.1-9.4$ \\
\hline
\end{tabular}

\subsection{Review of baseline data sets}

Several types of baseline field data sets were used to correlate this modelling study, including: the bathymetry data to construct the mesh domain and the meteorological, oceanographic and drainage channel volumetric flow data to define the sources for the hydrodynamic model. These data sets were collated as follows: The bathymetry data used was that published following the execution of the MELMARINE (Monitoring and Modelling Coastal Lagoons) field project funded by the EUINCOMed program reported by Thompson [2009]. The annual average metrological data was collated from the published literature (Thompson [2009], Shakweer [2005], Khalil [1990]). The main meteorological parameters defined for the model are the wind direction and speed, precipitation and evaporation rates. The annual fresh and drainage water inflow amount is approximately $6.6 \times 10^{9} \mathrm{~m}^{3}$. Thirty percent of the total inflow evaporated during the summer season, with the remaining being transferred to the Mediterranean Sea through the El-Gamil Lake sea connection. There are six major drains feeding Lake El-Manzala. The amount of inflow was $4.2 \times 10^{9} \mathrm{~m}^{3}$ annually Shakweer [2005] However, a recent study has reported that this volumetric flow rate has increased to $5,4 \times 10^{9} \mathrm{~m}^{3}$ per annum Thompson [2009]. This increment can be related to the increase of irrigation of field crops, especially rice. The maximum water inflow takes place during the summer season whilst the minimum inflows rates are experienced during the winter season. The predominant annual prevailing wind direction is from the north-west, and the average annual surface wind speeds experienced 
across the lake are between $5 \mathrm{~m} / \mathrm{s}$, at the northern border, to $2.5 \mathrm{~m} / \mathrm{s}$ in the southern region. The wind speed tends to be at its minimum in July and August and increases through November and January and reaches its maximum in April (Thompson et al. [2009], Shakweer [2005]).

\section{Hydrodynamic model development}

\subsection{Model description}

The hydrodynamic model used in this study is Finite Volume Coastal Ocean Model (FVCOM) developed by Chen et al. [2003]. The 3D unstructured-grid model computes: the change in water surface elevation; the velocity components, the temperature and salinity gradients; the sediment transport and deposition; and the water quality. The numerical domain is represented by an unstructured triangular grid in the horizontal plane. However, the models use the $\sigma$ transformation in the vertical plane to convert irregular bottom topography into a rectangular computational domain to simplify the numerical solution. An unstructured triangular mesh capable of capturing the features of an irregular coastline and a complex bathymetry is used. The numerical model employs the Mellor and Yamada [1982] level-2.5 turbulence closure method to parameterize the vertical eddy viscosity. The Smagorinsky [1963] eddy parameterization method is used to represent the horizontal diffusivity. FVCOM has been widely applied to investigate the circulation and transport process present in different types of lakes, estuaries, costal waters and open ocean zones. The model has recently been applied to investigate the monthly climatological circulation experienced within Lake Ontario, Canada Shore [2009]. Other recent studies that have employed FVCOM models include, Zheng et al [2003] who modelled the estuary flooding/drying process and water exchange within the Satilla River in Georgia; and Yang and Khangaonkar [2009] who studied the mixing and salinity intrusion process on the tidal estuary of the Skagit River, Washington, USA.

\subsection{Model grid and forcing factors}

An unstructured grid was generated to represent the lake basin. The triangular element grid size varied from approximately $50 \mathrm{~m}$ around the internal islands and near the drainage inlets and outlets up to a maximum of $900 \mathrm{~m}$ located in the relatively free area flow regions at the middle of the lake. The model grid consists of 5,983 elements and 3491 nodes in the horizontal plane (Fig. 2).

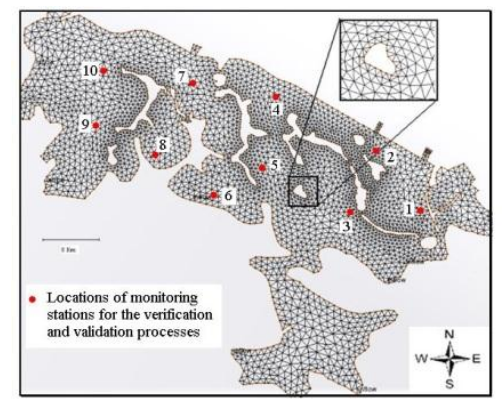

Figure 2The unstructured finite volume mesh for Lake El-Manzala.The measurement stations used toverify and validate the model are marked with a red dot

The water depth varies across the lake, from the deepest near the entrance to the Mediterranean Sea where the water depth is of $3.5 \mathrm{~m}$, to the minimum depth of $0.7 \mathrm{~m}$ in the south-eastern zone. The average water depth across the lake is $1 \mathrm{~m}$. The bathymetry data of Thompson [2009] was employed. Ten uniform vertical layers were specified in the water column in a $\sigma$ stretched coordinate system where the depth levels are of equal size. The Implicit Gravity Wave Radiation (IGWR) model 
introduced by Chapman [1985] is used to represent the lake outflow boundary condition. The hydrodynamic model is driven by the water flows emanating from the major drains feeding the lake, the surface wind shear across the lake, and the recorded seasonal evaporation and precipitation rates. The averaged seasonal drain inflow data were used to specify model boundary flow conditions. At the water surface, the seasonal average wind speeds and directions were applied uniformly across the entire water surface of the model domain.

\subsection{Model verification}

The numerical stability of the developed model was examined by checking the time to solve the predicted surface water levels at the ten measurement stations indicated on Figure 2. In Shore [2009] the solution of the FVCOM model is shown to be stable if the total energy represented by the kinetic and potential energies are bounded. It was confirmed that the lake model reaches an equilibrium state after the simulation of one year. The kinetic and potential energy equations are:

$E_{k}(t)=\int_{v} \rho\left(u^{2}+v^{2}\right) d V$

$$
E_{p}(t)=\int_{v} g \rho z d V-E_{p}(0)
$$

(2) where $\rho$ is density $u, v$ are the horizontal velocities, $g$ is gravity in the $z$ direction, $t$ is the time, $V$ is the water volume and $E_{p}(0)$ is the total initial mean potential energy at start up. The mean kinetic energy is zero initially. The time series of the computed kinetic and potential energy were checked for selective cases. These cases varied in time step and numbers of levels The External time step values are 5, 10, and $15 \mathrm{sec}$. Each time step was investigated at two different $\sigma$ levels numbers. The $\sigma$ levels values were; the 4 and 10 layer levels. The predicted values were computed over previous period of 365 days and confirmed that the kinetic and potential energy remain bounded in time which indicates the stability of the model. The time step chosen to solve the model satisfied the Courant Freidrichs Levy (CFL) stability condition. Mesh size sensitivity analysis were conducted and the predicted results were in agreement. Parametric studies concluded that the CFL model was stable when tested under different time steps and different water levels, and delivered similar computational results using different mesh size resolutions

\subsection{Model validation}

The predicted model lake salinity and temperature distributions were validated against the measured date of Thompson [2009]. Figure 3-a represents a comparison between the measured and predicted salinity levels at the 10 sampling stations. The water salinity is observed to varying between 3 PSU to 35 PSU across the lake. The predicted salinity is in a good agreement with the measured data at all stations. The error between the measured and predicted date is below $15 \%$ for all stations except stations 1, 2 and 3. The complex geometry of the central zone makes accurate salinity prediction for station 7 is hard to achieve. The predicted salinity of station 1 and 2 is lower than the measured data. However, these two stations are close to El Gamil lake-sea connection. The higher saline readings may be explained by the minor peneteration of a volume of sea waterin the winter months.. The predicted and measured temperatures at the sampling stations are shown in Figure 3-b. the results are in good agreements with no more than a $10 \%$ error. 


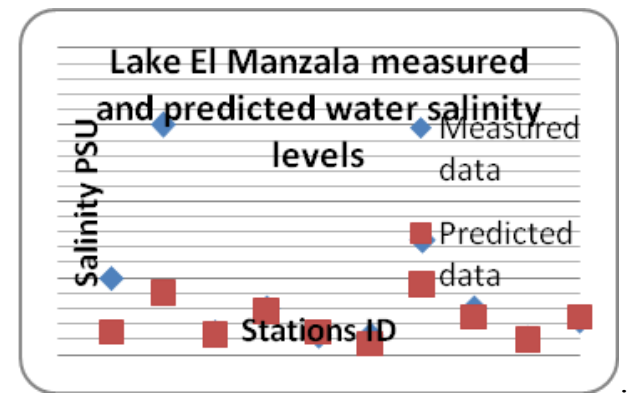

(a)

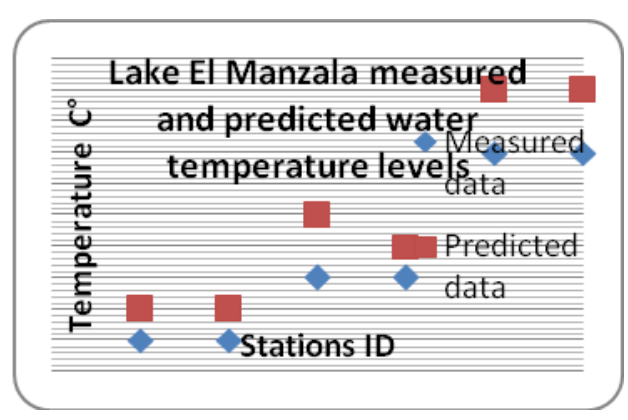

(b)

Figure 3A comparison of the measured and predicted (a) salinity and (b) temperature distribution data at the measurement stations indicated on figure 1.

\section{Results}

The base line salinity distribution predicted by the model is consistent with the base line model results of Peterson [2006] illustrated in Figure 4. The model confirms the low salinity levels measured in the southern part of the lake. Non saline drain water flows into the lake through the southern drains, which is mainly responsible for these low lake salinity readings. The high saline levels at the northern-western part are due to the mild penetration of salt water through a high saline buffer lagoon connected to the sea. There is some discrepancy in the salinity levels predicted in the south-western part of the lake. The lower computed levels of the current study are due to the inclusion of the El-Mataria drainage inflow not considered by the previous study of Peterson [2006].
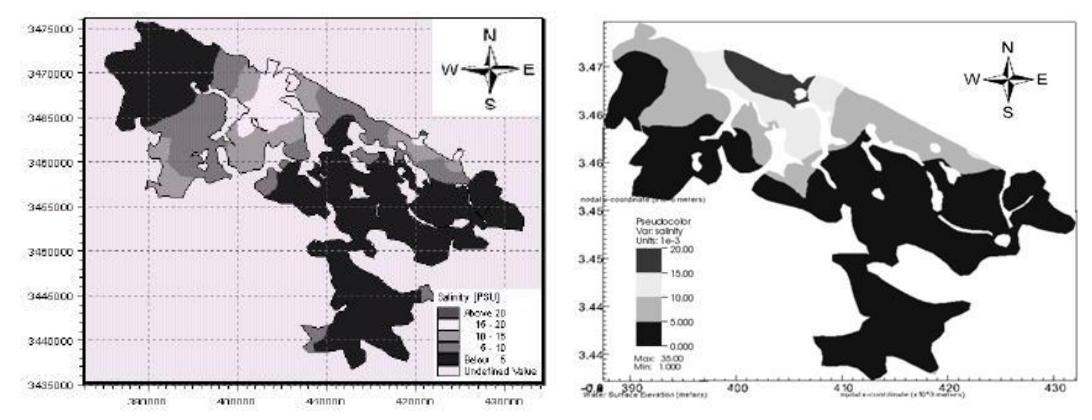

Figure 4Baseline salinity contours predicted by Peterson [2006] (left) and the current model baseline salinity contours (right)

In recent years there has been a diversion of up to $40 \%$ of the previous total flow channeled through the southern-western drainage channels, El-Mataria, Serw and Farasqr, to irrigate the settlements and farming activities located in the Sinai. This reduction in water inflow will have an adverse effect on the salinity levels experienced in the southern area of the lake. The effect on the predicted salinity distributions within the lake due to a diversion of $40 \%$ of the total drainage flows are presented in Figures 5 (a) and (b). For the base line case, where there is no diversion of the flow, the predicted simulation is demonstrated on Figure 5 (a). The predicted salinity levels in the lake due to the $40 \%$ diversion are shown in Figure 5 (b). A comparative analysis of these two predicted salinity maps concludes that the impact of such a diversion of water would be to increase the water salinity level from 3 PSU to 8 PSU at the western zone of the lake, which will affect the lake ecology. Consequently some low saline water fish species may migrate and salt water fish species tolerant of 
this salinity level may inhabit this sector of the lake. In addition it is predicted that the lake water levels may decrease and may evolve into a very shallow brackish marsh losing its reed beds and associated avian fauna. In addition this part might be reclaimed for agricultural purposes.
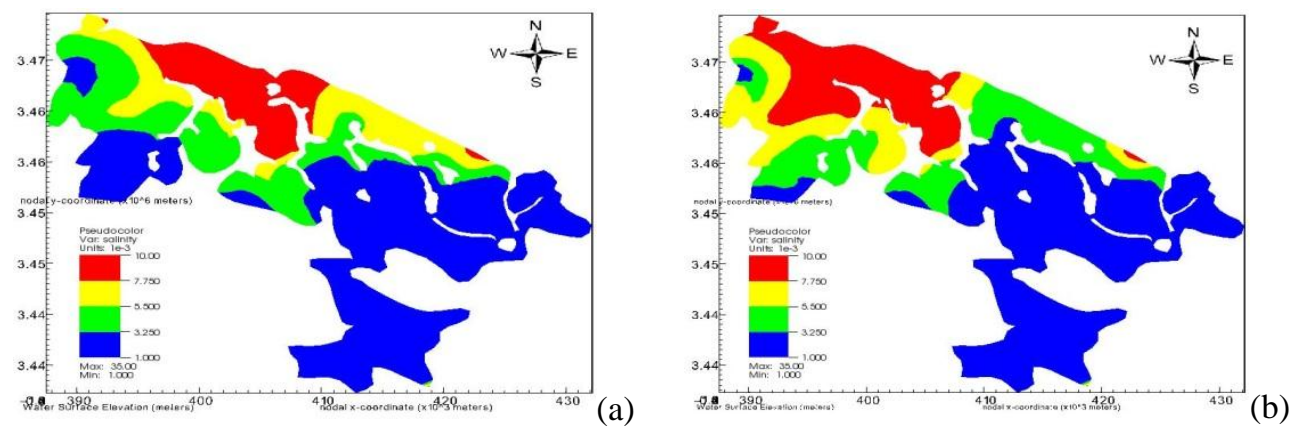

Figure 5Base line salinity distribution (a) before and (b) after the diversion of $40 \%$ of the original lake drain inflows

The predicted near surface flow patterns for the base case of the lake hydrology are illustrated in Figure 6. The velocity vectors indicate that, in the southern zone, the water movement is predominantly directed towards the north. In the northern upper part of the lake the water movement comes from the west where the water inflow occurs towards the east where the main coastal outlets exist. In this region the water flows parallel to the shoreline. This movement is primarlly due to the wind shear stress which is responsible for the water circulation inside the lake. The high velocity at the lake outlet is due to the confluence of the various exiting flows. The western zone of the lake (west of vertical dotted line on Figure 6) contains two major water circulation zones, both which progress the water circulation towards the eastern direction. Following a diversion of $40 \%$ of the drain water inflows, the predicted flow patterns remain in similar directions for almost the whole water domain. However, there are slightly different water patterns exhibited in the western zone where the direction of the predicted water flows are changed towards the south east.

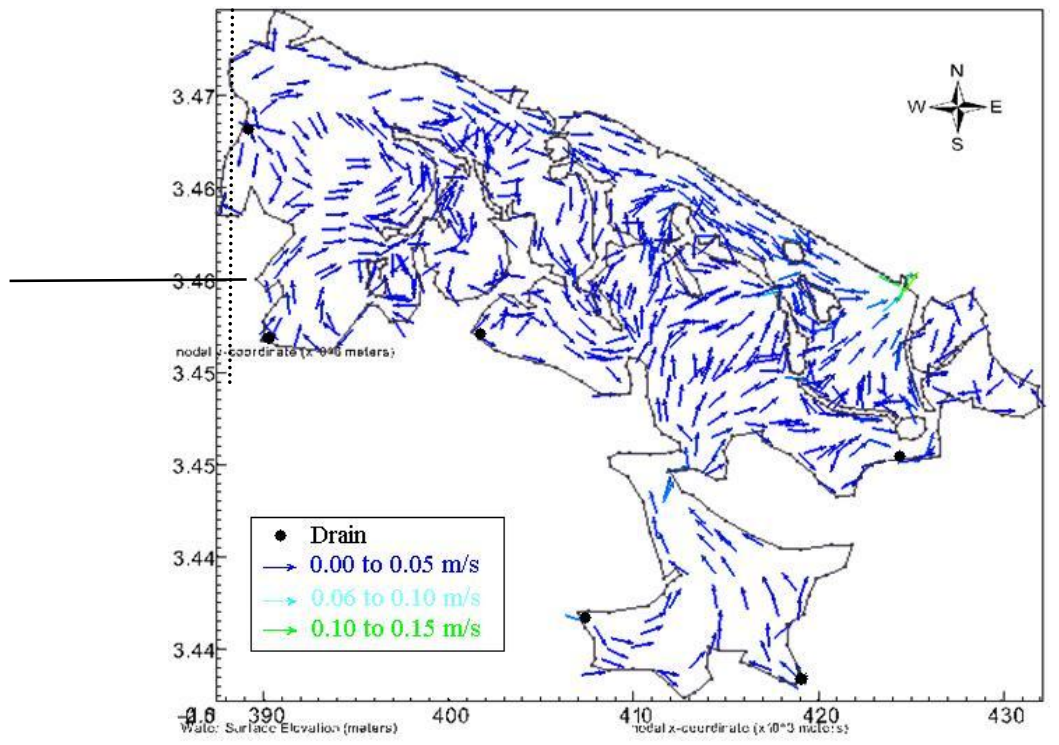

Figure 6 Lake El Manzala predicted near surface velocity vectors at $0.3 \mathrm{~m}$ depth (before $40 \%$ diversion) 
Some further lake management and water quality modelling scenarios are currently being investigated, including: the effect of employing water treatment plants to clean the drain waters; the influence of increased sedimentation and dredging; and, the influence of improved flow circulations on fish pond water quality and fish production levels.

\section{5- Remote sensing data}

Figure 7 shows the most resent bathymetry of Lake El-Manzala. The figure indicates that the lake is subjected to huge land reclamation in a quick manner. This process is expected to lead to bad water circulation. It is proposed to investigate the response of the lake water circulation after expanding the radial (narrow) channels. In addition, the available bathymetry data will give a good guide to select the best location where the expansion process will take place .

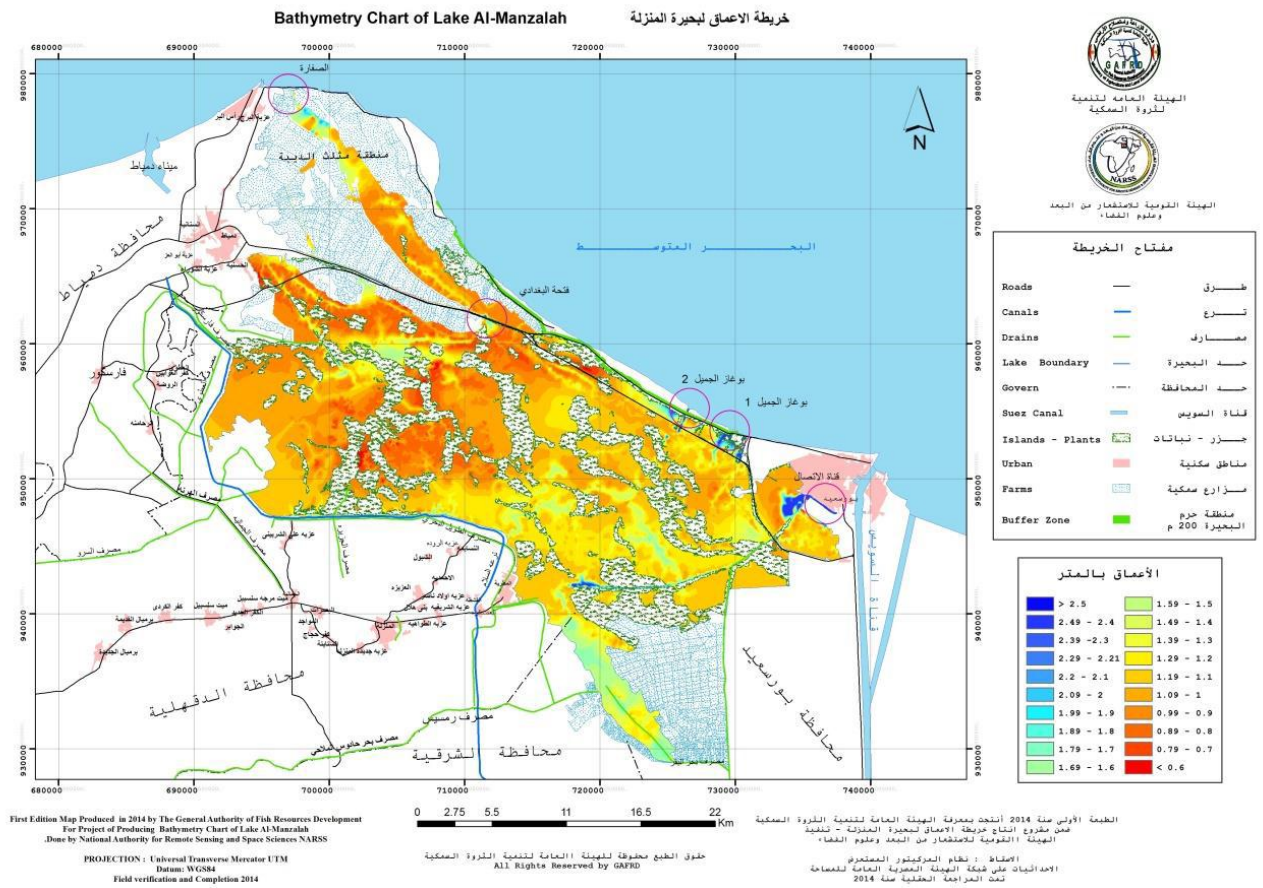

Figure 7 Lake El Manzala Bathymetry 2014

\section{Conclusions and Recommendations}

This is the first 3D field validated model applied to the sudy of the hydrology and water quality management of Lake El- Manzala. The preliminary results have confirmed the development of a successfully field validated hydrodynamic model of the lake. The computed potential and kinetic energy levels of the model lake remained bounded in time which confirmed the stability of the numerical model. The model reproduced the expected water circulation patterns. The calibrated model was applied to simulate the hydrodynamic effects produced by the reduction of the water inflow from the major eastern drains. The resulted data indicated a minor change to the hydrodynamic flows, but an increase in the salinity distribution in the western zone of the lake. Further studies are currently being undertaken to investigate the effects of these and other proposed changes on the water management and quality of the Lake. It is proposed to investigate the effect of the narrow channles expansion on the lake water circulation 


\section{ACKNOWLEDGMENTS}

This study was funded by the Egyptian government. We would like to thank Dr El Shenway I. and Dr Ahmed M.. We are also grateful to Dr Jennifer Shore for her suggestions.

\section{REFERENCES}

Abdel-Moati, A. D. and N.M. Dowidar, Trace elements status in surficial sediments of Lake Manzalah, Egypt, 14, 138-202, 1988.

Abdel-Star, A., Y. Geneid, Evaluation of heavy metal status in ecosystem of Lake Manzalah, Egypt, Global Journal Of Environmental Research, 3, 194-204, 2009.

Ayache, F., J. R. Thompson, R. J. Flower, A. Boujarra, F. Rouatbi and H. Makina, Environmental characteristics, landscape history and pressures on three coastal lagoons in the Southern Mediterranean Region: Merja Zerga (Morocco), Ghar El Melh (Tunisia) and Lake Manzala (Egypt), Hydrobiologia, 622, 15-43, 2009.

Blumberg, A. F. and L.H. Khanta, Open boundary conditions for circulation models, Journal of Hydraulic Engineering, 111, 260-264, 1985.

Chen, C., H. Liu, and R. Beardsley, An Unstructured Grid, Finite-Volume, Three-Dimensional, Primitive Equations Ocean Model: Application to Coastal Ocean and Estuaries, Journal of Atmospheric and Oceanic Technology, 20, 159-186, (2003).

Chapman, D. C, Numerical Treatment of Cross-Shelf Open Boundaries in a Barotropic Coastal Ocean Model. Journal of Physical Oceanography, 15, 1060-1075, 1985.

Donia N., M. H. Ahmed, Spatial investigation of the water quality in Lake Manzala using GIS techniques paper presented at $1^{\text {st }}$ Conf. on Envir. Change of Lakes, Lagoons and Wetlands of the Southern Mediterranean Region. Cairo, ECOLLAW, 2006.

Falconer, R. A., D. G. George, and P. Hall, 3D Numerical modelling wind driven circulation in a shallow homogenous lake. Journal of Hydrology, 124, 20, 1990.

Khalil, M. T., The physical and chemical environment of Lake Manzala, Egypt, Hydrobiologia, 169, 193-199, 1990.

KhedrA.-H. A., Aquatic macrophytes distribution in Lake Manzala, Egypt, International Journal of Salt Lake Research, 5, 221-239, 1997.

Kraïem, M. M., L. Chouba., M. Ramdani, M. H. Ahmed, J. R. Thompson and R. J. Flower, The fish fauna of three North African lagoons: specific inventories, ecological status and production, Hydrobiologia, 622, 133-146, 2009.

Mellor, G. and T. Yamada, Development of a Turbulence Closure Model for Geophysical Fluid Problems. Reviews Geophysics Space Physics, 20, 851 -875, 1982.

Petersen O., E. Rasmussen and C. Chambers, Hydro-Ecological Modelling of Coastal Lagoons. $1^{\text {st }}$ International Conference on Environmental Change of Lakes, Lagoons and Wetlands of the Southern Mediterranean Region, Cairo, ECOLLAW 252-257, 2006.

Rasmussen E., O. S. Petersen, J. R. Thompson, R. J. Flower and M. H. Ahmed , Hydrodynamicecological model analyses of the water quality of Lake Manzala (Nile Delta, Northern Egypt), Hydrobiologia, 622, 195-220, 2009.

Shakweer, L., Ecological and fisheries development of Lake Manzalah (Egypt) hydrography and Chemistry of Lake Manzalah. Egyptian Journal of Aquatic Research, 31, 251-270, 2005.

Shore, J. A., Modelling the circulation and exchange of Kingston basin and Lake Ontario with FVCOM, Journal of Ocean Modelling, 30, 106-114, 2009.

Siegel, F. R., Slaboda, M. L. \& Stanley, D. J., Metal pollution loading, Manzalah lagoon, Nile delta, Egypt: Implications for aquaculture, Environmental Geology, 23, 89-98, 1994. 
Smagorinsky, J., General Circulation experiments with the Primitive Equation, Monthly Weather Review 91, 99-165, 1963.

Thompson, J. R., R. J. Flower, M. Ramdani, F. Ayache, M. H. Ahmed, E. Rasmussen and O. S. Petersen, Hydrological characteristics of three North African coastal lagoons: insights from the MELMARINA project Hydrobiologia, 622, 45-84, 2009.

UNDP (1997) Lake Manzala Engineering wetland, United Nations Development program, project number: EGY/93/G31.

Wahaab, R. A. and M. I. Badway, Environmental impact of some chemical pollutants on Lake Manzala Int. Journal of Environmental Health Research, 7, 161-170, 1997.

Yang, Z. and T. Khangaonkar, Modelling tidal circulation and stratification in Skagit River estuary using unstructured grid ocean model. Ocean Modelling, 28, 34-49, 2009

Zheng, L., C. Chen, and H.Liu, A Modelling study of the Satilla River Estuary, Georgia. : Floodingdrying process and water exchange over the salt marsh estuary shelf complex Journal of Estuaries and coasts, 25, 651-669, 2003. 